\title{
Recycling of tailings from the Barruecopardo tungsten deposit for the production of glass
}

\author{
P. ALFONSO ${ }^{1}$, D. CASTRO ${ }^{1}$, M. GARCIA-VALLES ${ }^{2}$, M. TARRAGÓ2 ${ }^{2}$, O. TOMASA ${ }^{1}$, S. MARTÍNEZ ${ }^{2}$ \\ ${ }^{I}$ Dept. d'Enginyeria Minera i Recursos Naturals, Universitat Politècnica de Catalunya, Manresa, Spain \\ ${ }^{2}$ Dept. Cristal·lografia, Mineralogiai Dipòsits Minerals, Universitat de Barcelona, Barcelona, Spain
}

\begin{abstract}
Tailings from tungsten mining activities in the vicinity of the Barruecopardo (Salamanca) represent high environmental pollution. In this paper we present a study of the use of these wastes as raw materials for the manufacture of glass. This procedure aims to contribute to environmental remediation of mining areas through the vitrification, a process which offers an alternative for stabilization of hazardous wastes. In addition, the marketing of the obtained product would provide an additional income to the mining areas. The chemical composition of the tailings to be used as raw materials was determined by X-ray fluorescence and their mineralogy by X-ray diffraction. Wastes are of granitic composition enriched in potentially toxic. For this study a representative sample of mining wastes of sandy grain size was used to make the glass. On the basis of its composition, glass was formulated by adding 29.28 mass $\%$ of $\mathrm{CaCO}_{3}$ and 14.03 mass $\%$ of $\mathrm{Na}_{2} \mathrm{CO}_{3}$ and a green glass was produced. Crystallisation temperatures, obtained by DTA, were $875{ }^{\circ} \mathrm{C}$ and $1022{ }^{\circ} \mathrm{C}$ and the melting temperature was $1175^{\circ} \mathrm{C}$. The transition temperature of glass was of $644^{\circ} \mathrm{C}$. The temperatures for the fixed viscosity points and the working temperatures were obtained. A thermal treatment induced devitrification to produce a glass-ceramic made of nepheline and wollastonite. Leaching tests of the obtained glass confirm its capacity to retain potentially toxic elements.
\end{abstract}

Keywords: mining, tailings, mine waste, glass, recycling.

\section{Introduction}

Mining wastes constitute a serious environmental risk. To achieve the purity or concentration required to obtain the marketable product, it is necessary to apply processes that generate high volumes of tailings. The impact of mining wastes in the environment is even more concerning because, besides occupying large areas, it can lead to the emission of potentially toxic elements, as often the destabilization of contained sulphides produces acid mine drainage.

Intense mining to obtain tungsten in deposits associated with granitic rocks has long existed at the western part of the Iberian Peninsula. These activities have caused significant pollution in soils and water, especially with high levels of emission of As, as is the case with the old tungsten mines in Barruecopardo, Salamanca [1-3]. The strategic importance of tungsten [4] makes this activity of interest and currently many mines of this commodity are in process of reopening. This activity implies that economic and environmental aspects related to tailings management must be taken into account.

Vitrification is an alternative of environmental remediation through the transformation of wastes to glass in order to stabilize their pollutant components because their constituents are bound in a glassy stable matrix [5, 6]. Nevertheless, it is an expensive process that can usually only be applied if the obtained glass is reused in high-value applications [7]. Examples of these applications include a diversity of materials such as industrial wastes [8], fly ashes [9], sewage sludge [10] and pyrolized shales [11]. An advantage associated with the use of these materials lies in the fact that, as they have been already undergone industrial processes, they usually present good homogeneity and fine particle size. In 
addition, the mining costs for extraction are minimal. Furthermore, production of glass and glass-ceramic from mining wastes reduces the volume of waste exposed to the atmospheric processes and therefore prevent environmental pollution and at the same time yield additional economic returns.

The chemical composition of mining wastes originated from granitic rocks is similar to the most commonly used raw materials in glass making process, thus being suitable to make glass and ceramic materials [12-16]. The high environmental risk produced by tailings result of the tungsten mining [17] has led to several investigations to reduce this problem using these wastes to obtain glass-ceramic products [18], ceramic materials [19] or polymer-based composite materials [20].

The present work aims to determine the potential of tailings from W-rich granitic rocks from Barruecopardo to be used as raw materials in glass and glass-ceramic production. The tailings and the obtained glass have been characterised.

\section{Material and experimental procedures}

\section{Samples}

The Barruecopardo mine, located in Salamanca, is a W greisen-type ore deposit that consists mainly of granitic rocks with scheelite, wolframite, pyrite, abundant arsenopyrite and minor amounts of chalcopyrite, molybdenite and cassiterite. The activity at the Barruecopardo ore deposit developed from 1918 to 1985 and left millions of tons of mineral waste. Around $5 \mathrm{Mm}^{3}$ of waste material, occupying a surface of $28 \cdot 10^{4} \mathrm{~m}^{2}$, are stocked in the Barruecopardo tailings. A systematic sampling was undertaken in order to obtain 11 samples which are representative of the different areas of the tailing. The wastes were oven-dried at $90{ }^{\circ} \mathrm{C}$ during $24 \mathrm{~h}$; afterwards they were quartered and pulverized to a diameter under $45 \mu \mathrm{m}$ to obtain homogeneous samples.

Methods

The chemical compositions of raw tailing were determined by X-ray Fluorescence (XRF) using a Sequential X-ray Spectrophotometer (Philips PW 2400). Major elements were analysed in fused pearls (1/20 dilution in lithium tetraborate), two pearls for each sample. Trace elements were determined on pressed powder pellets. The spectrometer is calibrated by a set of more than 60 international standards.

The mineralogy of the tailing samples and the obtained glass-ceramic was determined by X-ray powder diffraction (XRD). The spectra were measured from powdered samples in a Bragg-Brentano PANAnalyticalX'Pert Diffractometer system (graphite monochromator, automatic gap, $\mathrm{K} \alpha$-radiation of $\mathrm{Cu}$ at $\lambda=1.54061 \AA$, powered at $45 \mathrm{kV}-40 \mathrm{~mA}$, scanning range $4-100^{\circ}$ with a $0.017^{\circ} 2 \theta$ step scan and a 50 s measuring time). Identification and semiquantitative evaluation of phases was made on PANanalyticalX'Pert HighScore software.

The mineral phases of the glass ceramic were observed by scanning electron microscopy (SEM) in order to determine the crystal morphologies and textural indicators of growth. The equipment was an environmental electron microscope ESEM Quanta 200 FEI, XTE 325/D8395 with an energy-dispersive X-Ray spectrometer (EDX)

After the evaluation of chemical composition results and considering the homogeneity of the tailing, the composition of a representative sample was used to formulate a glass with the following composition: $57 \%$ BP-7 waste, $29 \%$ of $\mathrm{CaCO}_{3}\left(\mathrm{PANREAC}\right.$, cod.121212) and $14 \%$ of $\mathrm{Na}_{2} \mathrm{CO}_{3}$ (PANREAC, cod.131648). The addition of $\mathrm{CaO}$ and $\mathrm{Na}_{2} \mathrm{O}$ had the function of lowering both the melting temperature of the raw materials and the viscosity of the melt. These additives ensure that the original glass can be produced at temperatures under $1500{ }^{\circ} \mathrm{C}$. 
The batch was introduced in an alumina-mullite crucible and placed inside a globular alumina furnace equipped with molybdenum disilicide Super Kanthal ${ }^{\circledR}$ and a Eurotherm ${ }^{\circledR} 902$ programmer. Heating began up to $450{ }^{\circ} \mathrm{C}$ at $1{ }^{\circ} \mathrm{C}$ $\mathrm{min}^{-1}$, followed by a second step of $2{ }^{\circ} \mathrm{Cmin}^{-1}$ up to $1450{ }^{\circ} \mathrm{C}$, with a $2 \mathrm{~h}$ long isotherm. The melts were cast into a metallic mould preheated to $350{ }^{\circ} \mathrm{C}$, and annealed near the glass transition temperature $\left(\mathrm{T}_{\mathrm{g}}\right)$ at $450{ }^{\circ} \mathrm{C}$ during $30 \mathrm{~min}$, followed by free cooling inside the kiln.

Colour glass was defined by measuring the spectral diffuse reflectance according to the CIE, 1931 XYZ colour space (CIE, Comission Internationale de l'Eclairage), which measures colour spaces and calculates the chromatic parameters. These parameters were measured with a Minolta CM-503i spectrophotometer over the visible range (400nm to $700 \mathrm{~nm}$ wavelength range). The spectrophotometer was fitted with a barium sulphate coated integrating sphere, and a standard illuminant $\mathrm{C}$ was used as a light source. A colorimeter is designed to evaluate the colour of a material according to international standards [21]. The tristimulus method is equivalent to the human eye system. It always has the same illuminant and measurements are performed under the same instrumental light source and illumination.

$\mathrm{T}_{\mathrm{g}}$ and dilatometric softening temperature (Ts) have been measured and calculated using a Linseis horitzontal dilatometer L76/1550. A powdered sample (diameter under $45 \mu \mathrm{m}$ ) was introduced in a SP5856/3605/10 sample carrier, then placed in a horizontal furnace and heated up to $1000{ }^{\circ} \mathrm{C}$ at a $10{ }^{\circ} \mathrm{Cmin}^{-1}$. Viscosity at $\mathrm{Tg}$ in these conditions has a constant value, independent of composition, of $10^{12.3} \mathrm{~Pa} \cdot \mathrm{s}[22]$.

Experimental viscosity-temperature curves $(\eta-T)$ have been drawn using the fixed points defined by [23] for hotstage microscopy (HSM) according to rule [24] and $\mathrm{T}_{\mathrm{g}}$ (obtained by dilatometry). $3 \mathrm{~mm}$-high test cylinders were conformed using samples powdered under $45 \mu \mathrm{m}$ and bound using a 1/20 solution of Elvacite ${ }^{\circledR}$ in acetone, conformed in an uniaxial press. Test cylinders were heated at a $5{ }^{\circ} \mathrm{Cmin}^{-1}$ rate from room temperature to $1500{ }^{\circ} \mathrm{C}$ in air atmosphere. All this process is recorded in pictures with ProgRes Capture Pro software. Picture analysis was performed with HotStage software, developed by the Departament de Llenguatges i Sistemes Informàtics, ETSEIB, UPC [25]. The fixed viscosity points are plotted in a graph and then fit to Vögel-Fulcher-Tammann (VFT, Eq. 1).

$$
\log \eta=A+\frac{B}{T-T_{0}}
$$

Where $\eta$ is the viscosity and parameters $\mathrm{A}, \mathrm{B}$ and $\mathrm{T}_{0}$ are determined from iterations of VFT equation.

The chemical composition of the obtained glass was used to calculate the theoretical viscosity-temperature curves using the model defined by Fluegel [26].

Leaching tests in acidic solution according to EPA SW 846 [27] standard have been used to establish the heavy metal inertization efficiency of the glass. The obtained solution has been analysed by inductively coupled plasma mass spectrometry and optical emission source (ICP-MS and ICP-OES).

Thermal evolution of the original glass was obtained by Differential Thermal Analysis and Thermogravimetry (DTA-TG) using a Netzsch equipment (STA 409C model). Analyses were carried in a dry air atmosphere with a flux of at $80 \mathrm{mLmin}^{-1}$ constant flow ratio, using an alumina crucible at a temperature range from 25 to $1300{ }^{\circ} \mathrm{C}$ with a linear temperature gradient set to $10^{\circ} \mathrm{Cmin}^{-1}$.

The original glass has been thermally treated according to DTA results to determine the mineralogical evolution and make a glass-ceramic. Different original glass fragments were heated inside the kiln at $2{ }^{\circ} \mathrm{Cmin}^{-1}$ to $750{ }^{\circ} \mathrm{C}$, followed by a $2 \mathrm{~h}$ isothermal step, further heating up to $875^{\circ} \mathrm{C}$, a second $2 \mathrm{~h}$ isothermal step, heating up to $1075^{\circ} \mathrm{C}$ and a final $2 \mathrm{~h}$ isotherm.

\section{Results and discussion}




\section{Raw tailing characterization}

The tailings from Barruecopardo are homogeneous both from the chemical and the mineralogical point of view. Table 1 shows the chemical composition of tailing samples. The major components are $\mathrm{SiO}_{2}, 74-78$ mass $\% ; \mathrm{Al}_{2} \mathrm{O}_{3}, 12-14$ mass\%; $\mathrm{TiO}_{2}$, 0.1-0.2 mass\%; $\mathrm{Fe}_{2} \mathrm{O}_{3}, 0.8-1.3$ mass\%; $\mathrm{Na}_{2} \mathrm{O}, 2.2-2.9$ mass\%; $\mathrm{CaO}, 0.4-0.6$ mass\%; $\mathrm{MgO}, 0.1-0.4$ mass\%; $\mathrm{K}_{2} \mathrm{O}$, 5.1-6.2 mass\% and $\mathrm{P}_{2} \mathrm{O}_{5}, 0.3-0.4$ mass\%. Relevant potentially toxic elements which are over EPA concentration limits for solid wastes are As (83-632 ppm), Ba (107-212 ppm), Cr (5-21 ppm), Pb (23-29 ppm), Sn (1016 ppm), Sr (32-59 ppm) and Zn (30-60 ppm). High W contents (500-700 ppm) have also been obtained.

XRD patterns of tailing samples evidence that the main mineral phases are quartz $\left[\mathrm{SiO}_{2}\right]$, albite $\left[\mathrm{NaAlSi}_{3} \mathrm{O}_{8}\right], \mathrm{K}-$ feldspar $\left[\mathrm{KAlSi}_{3} \mathrm{O}_{8}\right]$ and muscovite $\left[\mathrm{KAl}_{2}\left(\mathrm{Si}_{3} \mathrm{Al}\right) \mathrm{O}_{10}(\mathrm{OH}, \mathrm{F})_{2}\right]$, together with minor contents of hematite $\left[\mathrm{Fe}_{2} \mathrm{O}_{3}\right]$ and kaolinite $\left[\mathrm{Al}_{2}\left(\mathrm{Si}_{2} \mathrm{O}_{5}\right)(\mathrm{OH})_{4}\right]$.

\section{Glass}

The major components of glass calculated from the composition of the raw materials are $\mathrm{SiO}_{2}, \mathrm{Al}_{2} \mathrm{O}_{3}, \mathrm{CaO}$ and $\mathrm{Na}_{2} \mathrm{O}$. The glass network-forming oxides are $\mathrm{SiO}_{2}, 59.0$ mass\% and $\mathrm{Al}_{2} \mathrm{O}_{3}$ (10.7 mass\%), with relatively low contents of $\mathrm{SiO}_{2}$ and high contents of $\mathrm{Al}_{2} \mathrm{O}_{3}$, when comparing to a soda-lime silicate glass (Table 2). The concentrations of networkmodifying alkaline oxides, $\mathrm{Na}_{2} \mathrm{O}$ and $\mathrm{K}_{2} \mathrm{O}$, are 8.2 mass $\%$ and 4.2 mass\% respectively. Network-stabilizer alkaline earth oxide $\mathrm{CaO}$ is 16.4 mass\%. Other network-modifiers, such as $\mathrm{MgO}\left(0.2\right.$ mass\%), $\mathrm{MnO}(0.01$ mass $\%)$ and $\mathrm{P}_{2} \mathrm{O}_{5}$ $(0.28$ mass $\%)$ are at low concentrations. $\mathrm{TiO}_{2}(0.1$ mass $\%)$ and $\mathrm{Fe}_{2} \mathrm{O}_{3}(0.9$ mass\% $\%)$ are also scarce.

The green colour of the glass is attributed to Fe content at the raw material, approximately $1 \%$ in reduced state. The main optical aspects and chromaticity coordinate values $\left(\mathrm{L}^{*}, \mathrm{a}^{*}, \mathrm{~b}^{*}, \mathrm{C}^{*}\right.$ and $\mathrm{h}$ ) of the glass are $\mathrm{a}^{*}=-0.34, \mathrm{~b}^{*}=1.16$, $\mathrm{L}^{*}=0.7, \mathrm{C}=1.21$ and $\mathrm{h}=106.34$. The obtained $\mathrm{h}$ value for the glass of Barruecopardo tailing is in good agreement with green coloured glass.

Glass transition calculated from the dilatometric curve of the original glass occurs at a temperature of $644{ }^{\circ} \mathrm{C}$. Dilatometric softening temperature (another indicator of glass deformation before crystallization) is $698{ }^{\circ} \mathrm{C}$.

The temperatures of fixed viscosity points determined by HSM of the original glass are shown in Figure 1 and listed in Table 3. These experimental values were fit to VFT equation to plot the evolution of viscosity with temperature of the original glass BP7 in Figure 2. First shrinkage, which corresponds to a viscosity of $10^{9} \mathrm{~Pa} \cdot \mathrm{s}$, is obtained at 854 ${ }^{\circ} \mathrm{C}$; maximum shrinkage, $10^{7.2} \mathrm{~Pa} \cdot \mathrm{s}$, at $989^{\circ} \mathrm{C}$; softening, $10^{5.1} \mathrm{~Pa} \cdot \mathrm{s}$, at $1179{ }^{\circ} \mathrm{C}$; ball, $10^{4.4} \mathrm{~Pa} \cdot \mathrm{s}$, at $1253{ }^{\circ} \mathrm{C}$; half ball, $10^{3.6} \mathrm{~Pa} \cdot \mathrm{s}$, at $1344{ }^{\circ} \mathrm{C}$; and flow, $10^{3.1} \mathrm{~Pa} \cdot \mathrm{s}$, at $1406{ }^{\circ} \mathrm{C}$. These values are inside the same magnitude range than those considered for glasses obtained using sewage sludge from wastewater treatment plants in Egypt [28] and tailings from mining activities in Bolivia [29].

A mathematical model for industrial glasses [26] predicts an evolution of viscosity with temperature which is not in good agreement with the experimental results (Figure 2). Although at the glass transition $\left(10^{12.3} \mathrm{~Pa} \cdot \mathrm{s}\right)$ the theoretical curve only differs from the experimental value by a few degrees, the deviation grows quickly with increasing temperature. In the low viscosity range $\left(10^{2}-10^{4} \mathrm{~Pa} \cdot \mathrm{s}\right)$ measured viscosity is more than $300{ }^{\circ} \mathrm{C}$ higher than predicted viscosity. This model is designed for industrial glasses that have more restricted compositions, such as lower $\mathrm{Al}_{2} \mathrm{O}_{3}$ and which do not bear trace amounts of potentially toxic elements (the case of BP-7 and most glasses made of wastes) as the combination of these elements influences viscosity in still not completely understood mechanisms.

The obtained significant workability values are the lower annealing point, $10{ }^{13.5} \mathrm{~Pa} \cdot \mathrm{s}$, at $595{ }^{\circ} \mathrm{C}$; upper annealing point, $10^{12} \mathrm{~Pa} \cdot \mathrm{s}$, at $671{ }^{\circ} \mathrm{C}$; forming range, $10^{3-8} \mathrm{~Pa} \cdot \mathrm{s}, 926-1419{ }^{\circ} \mathrm{C}$; glass conditioning range, $10^{2-3} \mathrm{~Pa} \cdot \mathrm{s}, 1419-1556{ }^{\circ} \mathrm{C}$; and melting range, $10^{1-2} \mathrm{~Pa} \cdot \mathrm{s}>1556^{\circ} \mathrm{C}$. Table 3 summarizes the temperatures of the upper and lower annealing points, 
forming interval, interval conditioning and melting range together with their corresponding viscosities [30]. The viscous behaviour of the glass-forming melt at a certain temperature allows casting the melt inside a mould along a fairly wide temperature range, by various processes, such as straining, blowing, stretching, rolling or pressing. Each conformation method will require appropriate thermal conditions in the work area in order to stabilize and maintain its viscosity enough time to ensure casting. The producer must reach a compromise between the viscosity required for each moulding method and the cadence and performance in manufacturing automated systems. In the present case, the range of workability of the glass is between 1190 and $1556^{\circ} \mathrm{C}$.

The temperature increase in the $10^{6}-10^{3} \mathrm{~Pa} \cdot \mathrm{s}$ viscosity range for BP-7 is $326^{\circ} \mathrm{C}$ (Figure 2). Temperature variations under $400{ }^{\circ} \mathrm{C}$ in this interval correspond to the rheological behaviour of so-called short glasses [30], which are suitable for automatic manufacturing. When this difference is larger than $400{ }^{\circ} \mathrm{C}$, they are called long glasses, and are suitable for manual shaping.

The analysis of leachates shows that the cations have been introduced in the glass structure because the concentrations of potentially toxic elements in the liquid are either very low $(\mathrm{Zn}, \mathrm{Cr}, \mathrm{Ni}, \mathrm{Pb}, \mathrm{Ba})$ or directly below the detection limit (As, Se, Cd, W, Ag). These results comply with the requirements stated in EPA SW 846 [27] as the obtained glass has a good chemical durability (with a negligible leaching).

DTA obtained from annealed original glass powders is shown in Figure 3. The formation crystalline phases is represented by the occurrence of a single exothermal event. In this study, a small exothermic peak at $875{ }^{\circ} \mathrm{C}$ and another, more prominent, at $1022{ }^{\circ} \mathrm{C}$, correspond to crystallization temperatures $\left(\mathrm{T}_{\mathrm{c}}\right)$. The last peak is an endothermic event at $1200{ }^{\circ} \mathrm{C}$ attributed to the melting of the system. The glass has been thermally treated in the furnace on the basis of these values in order to make a glass-ceramic and determine which mineral phases are formed during the heating process.

A glass-ceramic was produced by crystallization of the original glass. The first phase crystallized at $875^{\circ} \mathrm{C}$ and the second at $1022{ }^{\circ} \mathrm{C}$. After crystallization, melting occurs at $1175{ }^{\circ} \mathrm{C}$, which is the temperature of the eutectic of $\mathrm{NaAlSiO}_{4}-\mathrm{CaSiO}_{3}$ system.

XRD patterns corresponding to glass treated over $T_{c}$ show the mineral association produced in the devitrification process, constituted by $47 \%$ nepheline $(\mathrm{Na}, \mathrm{K}) \mathrm{AlSiO}_{4}$ and $53 \%$ wollastonite $\left(\mathrm{CaSiO}_{3}\right)$ as presented in Figure 4 . The bump of the diffractogram between 20 and $402 \theta^{\circ}$ evidences the existence of a remaining amorphous phase.

\section{Glass-ceramic}

The newly formed phases in thermally treated original glass are shown in Figure 5. The two different morphologies formed, which can be correlated with XRD results, are equidimensional crystals of nepheline and needle-like wollastonite crystals. The amorphous phase deduced in the diffractogram has also been identified by SEM in the central part of thermally treated glass, corresponding to residual glass matrix. In the region observed in Figure 5A, nepheline and wollastonite crystals are immersed in the glassy matrix. In the fully crystalline region, nepheline and wollastonite are intergrown (Figure 5B, C). The typical fibrous texture of wollastonite is shown in Figure 5D.

In order to further prevent waste generation and accumulation and to limit consumption of certain raw materials, some waste products from other industries could be used as fluxes in the manufacture of this glass. $\mathrm{CaO}$ may be obtained from marble dust generated in the quarries of this material during cutting operations. In the case of sodium, the perfect option would be to use a waste product of sodium carbonate process.

\section{Conclusions}


The Barruecopardo tailing has homogeneous chemical and mineralogical composition. The $\mathrm{SiO}_{2}$ and $\mathrm{Al}_{2} \mathrm{O}_{3}$ contents make it suitable to produce glass after the addition of $\mathrm{CaO}$ and $\mathrm{Na}_{2} \mathrm{O}$ as modifying oxides. Therefore, vitrification could be an efficient solution for the valorization and inertization of these wastes, which are enriched in toxic elements such as $\mathrm{As}, \mathrm{Ba}, \mathrm{Cd}, \mathrm{Cr}, \mathrm{Pb}$ and $\mathrm{Zn}$ (concentration over EPA limits for solid wastes).

The glass transition temperature is $644{ }^{\circ} \mathrm{C}$; the glass production should reach temperatures of at least $1556{ }^{\circ} \mathrm{C}$ (lower limit of the melting range). As these temperatures are too high for an industrial process, the composition of the original glass should be changed to increase the content of modifiers, moving its composition closer to the most basic rocks, and therefore lowering its melting temperatures.

The original glass has a green colour and it could be used with marketable purposes, thus giving an economic value to the residues and at the same time minimizing the environmental problems. Leaching tests of the obtained glasses confirm their capacity to retain potentially toxic elements. The main crystalline phases obtained from the devitrification process of the glass are wollastonite and nepheline.

In spite of high energetic consumption and the attached economic costs, the reuse of Barruecopardo tailings is desirable from the social and environmental point of view to reduce the amount of unusable material now emplaced at the deposits, and to sequestrate the pollutant components in the glassy matrix, once their composition is adequately optimised.

\section{Acknowledgements}

This work is part of the OptimOre project. This project has received funding from the European Union's Horizon 2020 research and innovation programme under grant agreement No 642201. Funds from the Fundació Bosch I Gimpera Project 307466 and the Consolidated Group for Research of Mineral Resources, 2014 SGR-1661 (Recursos Minerals: jaciments, aplicacions, sostenibilitat) were contributed. The authors would like to thank the staff of the Centres Científics I Tecnològics of the University of Barcelona (CCiTUB) for their technical support.

\section{References}

[1] Garcia-Sanchez A, Alvarez-Ayuso E. Arsenic in soils and waters and its relation to geology and mining activities (Salamanca Province, Spain). J Geoch Explor. 2003;80:69-79.

[2] Otones V, Álvarez-Ayuso E, García-Sánchez A, Santa Regina I, Murciego A. Arsenic distribution in soils and plants of an arsenic impacted former mining area. Environ Pollut. 2011;159:2637-2647.

[3] Murciego A, Álvarez-Ayuso E, Pellitero E, Rodríguez, MA, García-Sánchez A, Tamayo A, Rubio J, Rubio F, Rubin J. (2011). Study of arsenopyrite weathering products in mine wastes from abandoned tungsten and tin exploitations. J Hazard Mater. 2011;186:590-601.

[4] Europen Union. Report on critical raw materials for the EU 2014, pp 41.

[5] Bingham PA, Hand RJ. Vitrified metal finishing wastes: I. Composition, density and chemical durability. J Hazard Mater. 2005;119:125-133.

[6] Bingham PA, Hand RJ, Forder SD, Lavaysierre A. Thermal and structural characterisation. J Hazard Mater. 2005;122:129-138.

[7] Binhussain MA, Marangoni M., Bernardo E, Colombo P. Sintered and glazed glass-ceramics from natural and waste raw materials. Ceram Int. 2014;40:3543-3551. 
[8] Pérez JA, Terradas R., Seijas MM, Manent R, Martínez S.. Inertization of industrial wastes in ceramics materials. Ind Ceram. 1996;16: 7-11.

[9] Haugsten KE, Gustavson B. Environmental properties of vitrified fly ash from hazardous and municipal waste incineration. Waste Manage. 2000;20:167-176.

[10] Garcia-Valles M, Avila G, Martinez S, Terradas R, Nogués JM. Heavy metal-rich wastes sequester in mineral phases through a glass-ceramic process. Chemosphere 2007;68:1946-53.

[11] Rangel BF, Viana MM, Fonseca MVA, Dweck J, Tavares LM. Thermal characterization of a new green ceramic material by heating microscopy, thermogravimetry and differential thermal analysis. J Therm Anal Calorim. 2015;121:115-125.

[12] Raigon-Pichardo M, Garcia-Ramos G, Sanchez-Soto PJ. Characterization of a waste washing solid product of mining granitic tin-bearing sands and its application as a ceramic raw material. Resour Conserv Recy. 1996; 17:109-124.

[13] Ferreira JMF, Torres PMC, Silva MS, Labrincha, JA. Recycling of granite sludge in brick-type and floor tiletype ceramic formulations. Euroceram News 2003; 14:1-5.

[14] Monteiro SN, Peçanha LA, Vieira CMF. Reformulation of roofing tiles body with addition of granite waste from sawing operations. J Eur Ceram Soc. 2004;24:2349-2356.

[15] Segadães AM, Carvalho MA, Acchar W. Usingmarble and granite rejects to enhance the processing of clay products. Appl Clay Sci. 2005;30:42-52.

[16] Hojamberdiev M, Eminov A, Yunhua X. Utilization of muscovite granite waste in the manufacture of ceramic tiles. Ceram Int. 2010;37:871-76.

[17] Liu,CP, Luo CL, Gao Y, Li FB, Lin LW, Wu CA, Li XD. Arsenic contamination and potential health risk implications at an abandoned tungsten mine, southern China. Environ Pollut. 2010;158:820-826.

[18] Peng K, Lv C, Yang H. Novel preparation of glass ceramics from amorphized tungsten tailings. Ceram Int. 2014;40:10291-10296.

[19] Durán Suárez J, Montoya Herrera J, Silva AP, Peralbo Cano R., J. Castro-Gomes JP. Validación de nuevos materiales cerámicos a partir de rocas de desecho de minería. Propiedades mecánicas. Bol Soc Esp Ceram Vidr. 2014;53: 279-288.

[20] Castro-Gomes JP, Silva AP, Peralbo Cano R, Durán Suárez J, Albuquerque A. Potential for reuse of tungsten mining waste-rock in technical-artistic value added products. J Clean Prod. 2012; 25: 34-41.

[21] CIE. Technical report, colorimetry. 1931. Commission Internationale de L'Eclairage.

[22] Engels M, Link S. Bubble control in ceramic glazes. Interceram. 2006;3:152-6.

[23] Scholze H. Der Einfluss von Viskosität und Oberflächenspannung auf erhitzungsmikroskopische Messungen an Gläsern. Ber Dtsch Keram Ges. 1962;39:63-8.

[24] DIN 51730. Determination of ash fusion behaviour, German Standard, 1976.

[25] Garcia-Valles M, Hafez H, Cruz-Matías I, Vergés E, Aly MH, Nogués JM, Ayala, D, Martinez S. Calculation of viscosity-temperature curves for glass obtained from four wastewater treatment plants in Egypt. J Therm Anal Calori. 2013;111:107-114.

[26] Fuegel A. Glass Viscosity Calculation based on a Global Statistical Modeling Approach. Glass Technol.Europ. J Glass Sci Technol. 2007;A,48:13-30.

[27] Environmental Protection Agency. norma EPA. Test Methods for Evaluating Solid Waste: Physical/Chemical Methods. 1986;SW-846, $3^{\text {a }}$ Ed. Office of Solid Waste and Emergency Response, U. S. 
[28] Garcia-Valles M, Aly MH, El-Fadaly E, Hafez H, Nogués JM, Martinez S. Producción de materiales vitrocerámicos obtenidos a partir de lodos procedentes de una estación de depuración de aguas residuales urbanas en la Ciudad de El-Sadat (Egipto). Bol Soc Esp Ceram Vidr. 2011;50:219-28.

[29] Arancibia JRH, Alfonso P, García-Valles M, Martínez S, Parcerisa D, Canet C, Romero FM. Obtención de vidrio a partir de residuos de la minería del estaño en Bolivia. Bol Soc Esp Ceram Vidr. 2013;52:143-150.

[30] Fernandez Navarro JM. El Vidrio. Ed. CSIC y Centro Nacional del Vidrio, Madrid, 1991. 


\section{Figure captions}

Fig. 1 Photomicrographs of the glass cylindrical probe: shapes corresponding to the fixed viscosity points obtained during the experimental procedure.

Fig. 2 Viscosity-temperature curves obtained both experimentally and by the application of the theoretical model.

Fig. 3 DTA curve of original glass. The exothermal peaks correspond to crystallization of nepheline and wollastonite and the endothermic event is the melting point of the system.

Fig. 4 XRD pattern of glass ceramic showing the mineral phases produced in the devitrification process.

Fig. 5 SEM images of the obtained glass-ceramic: a Glass ceramic formed by nepheline, wollastonite and residual glass matrix in the central part of sample, b Overview of the intergrowth of wollastonite fibrous crystal texture with tabular nepheline crystals, $\mathbf{c}$ Detail of a wollastonite-nepheline intergrowth, $\mathbf{d}$ Wollastonite needle-like crystals. 


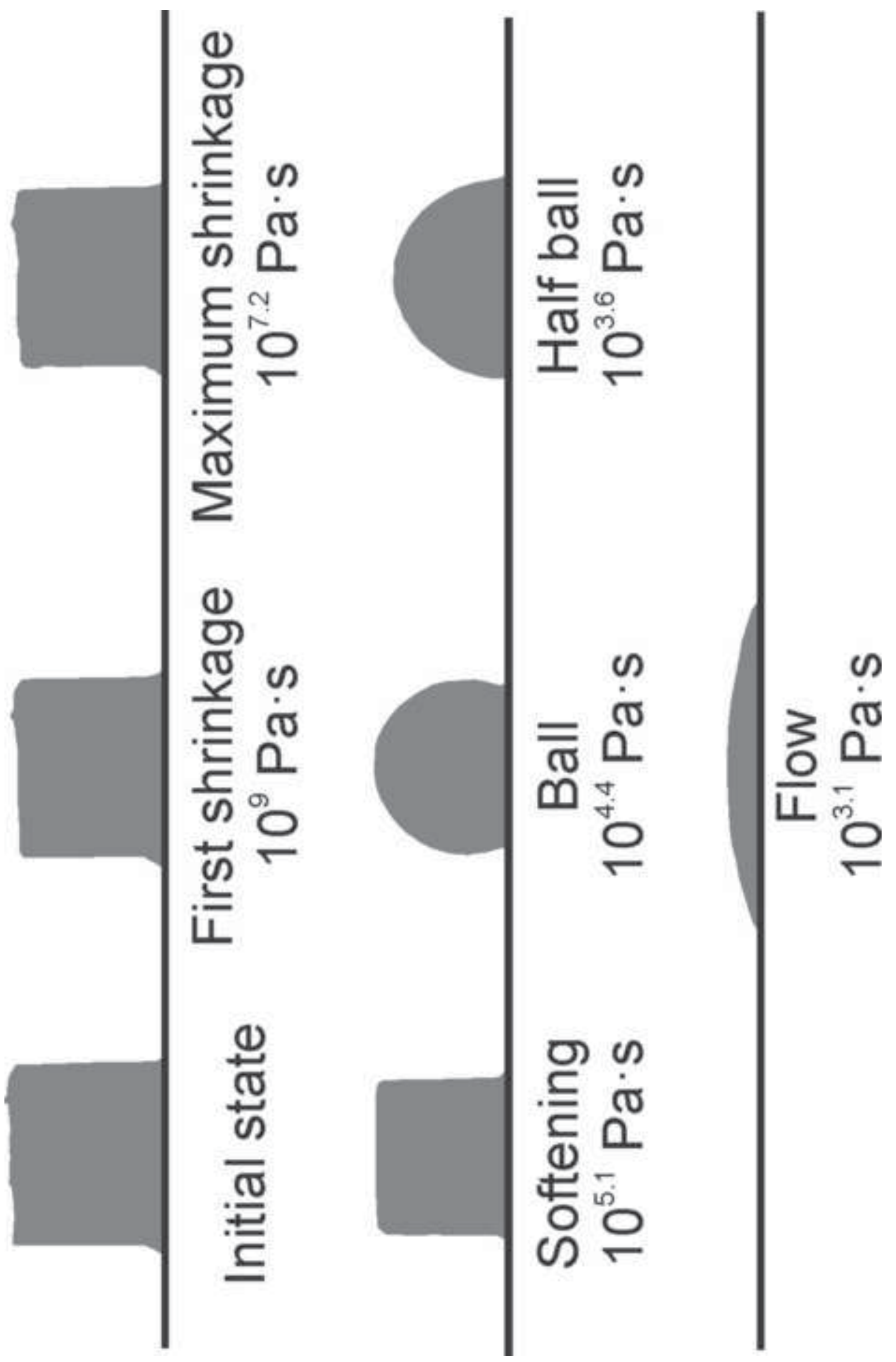




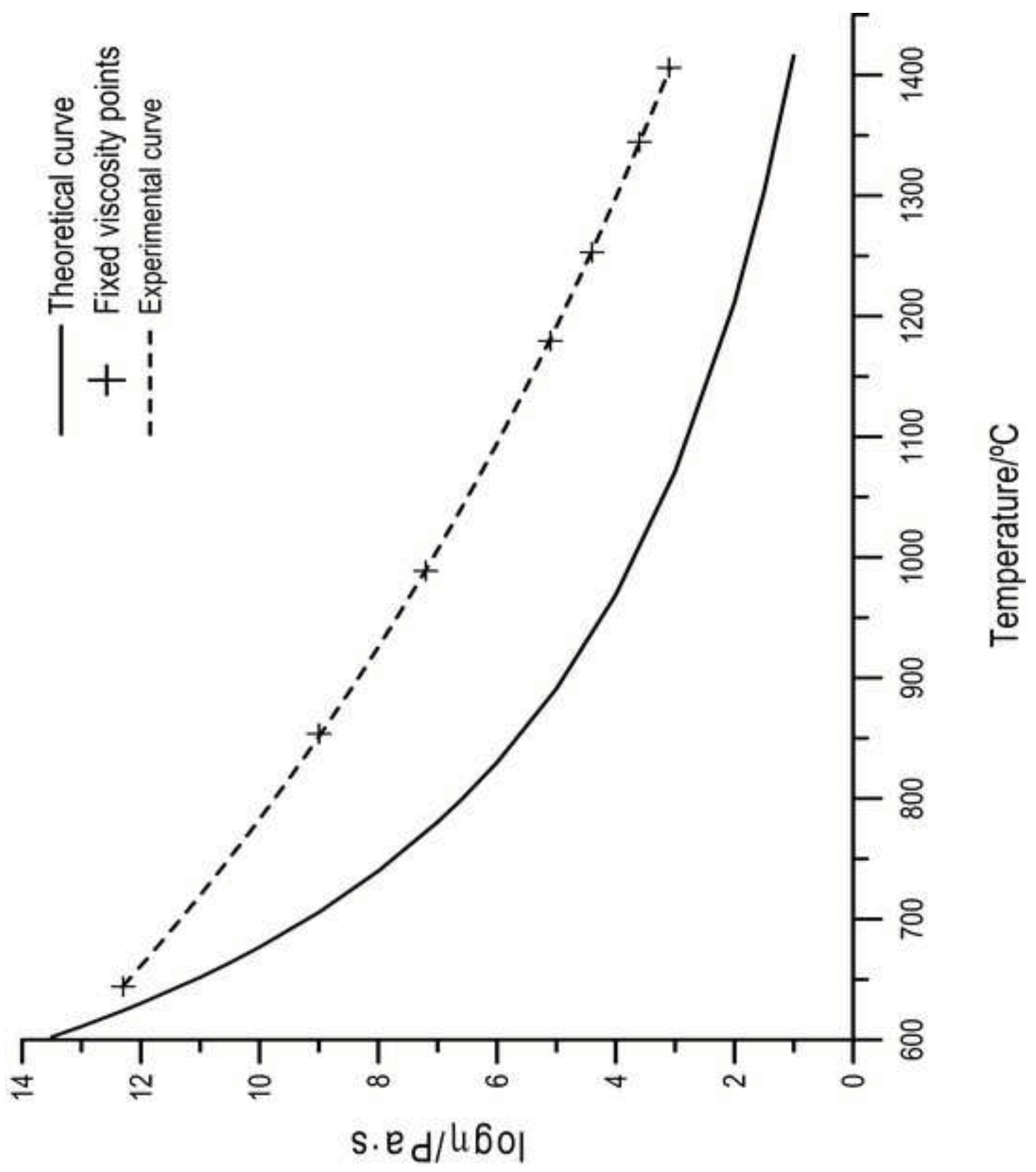




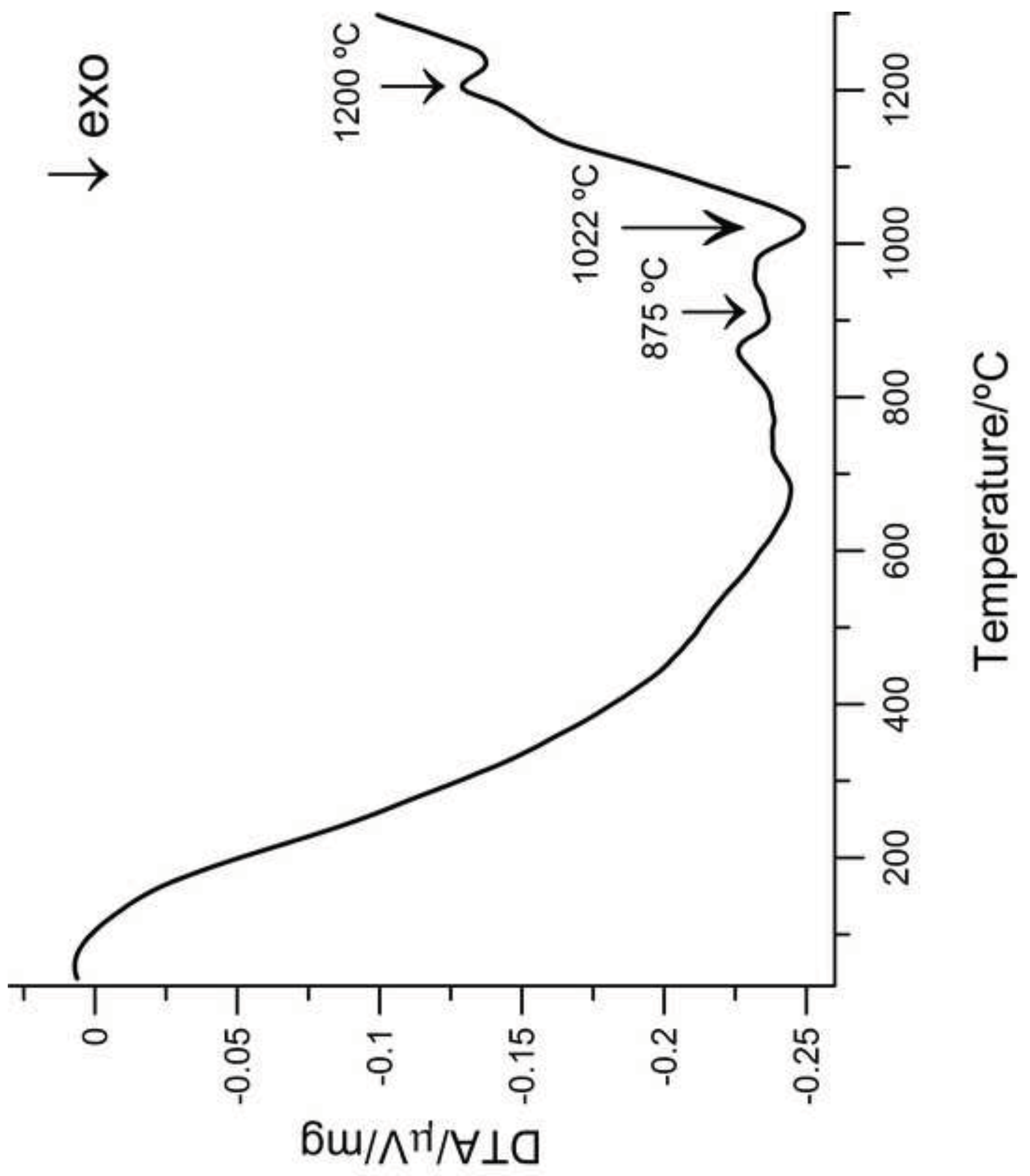



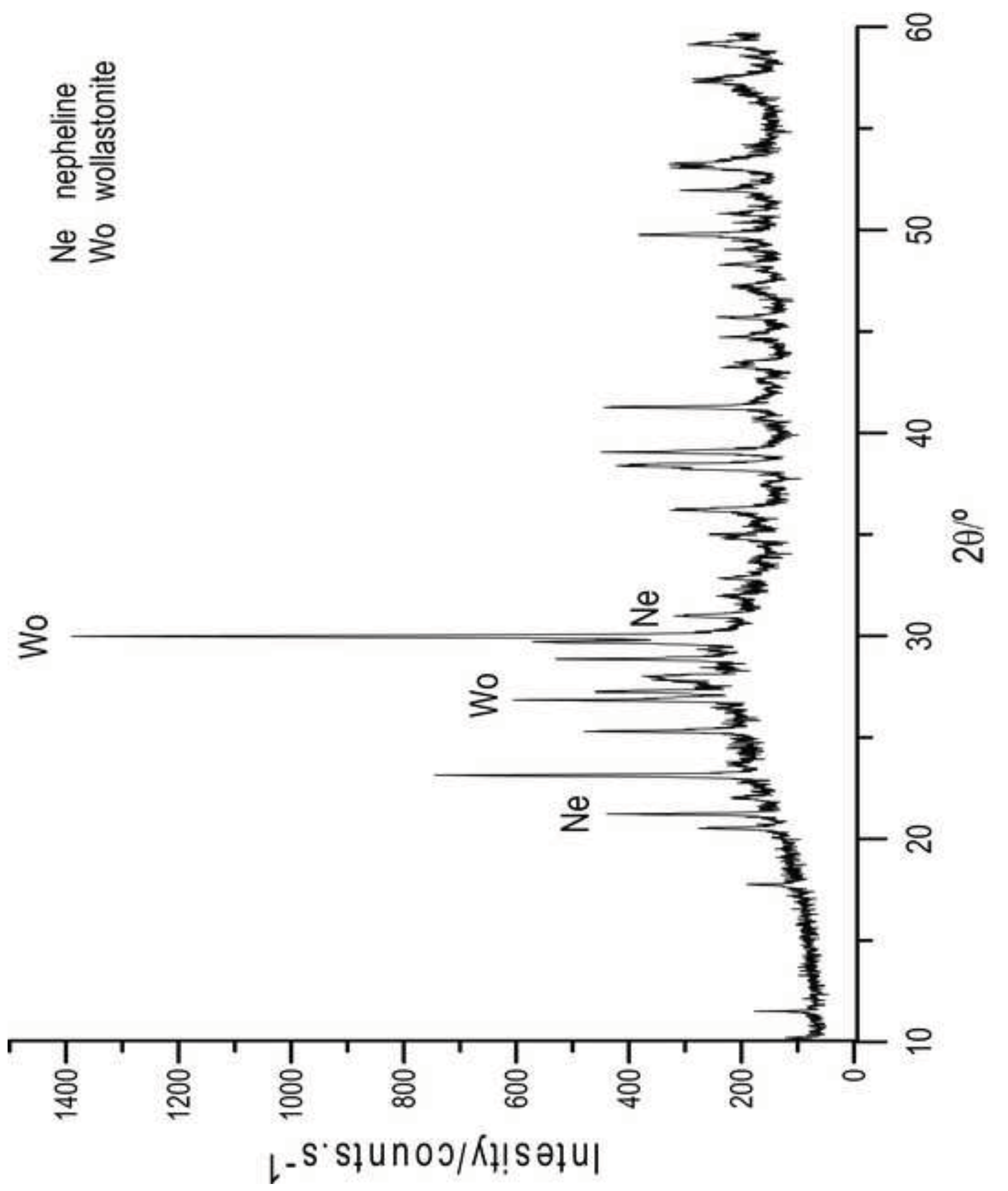

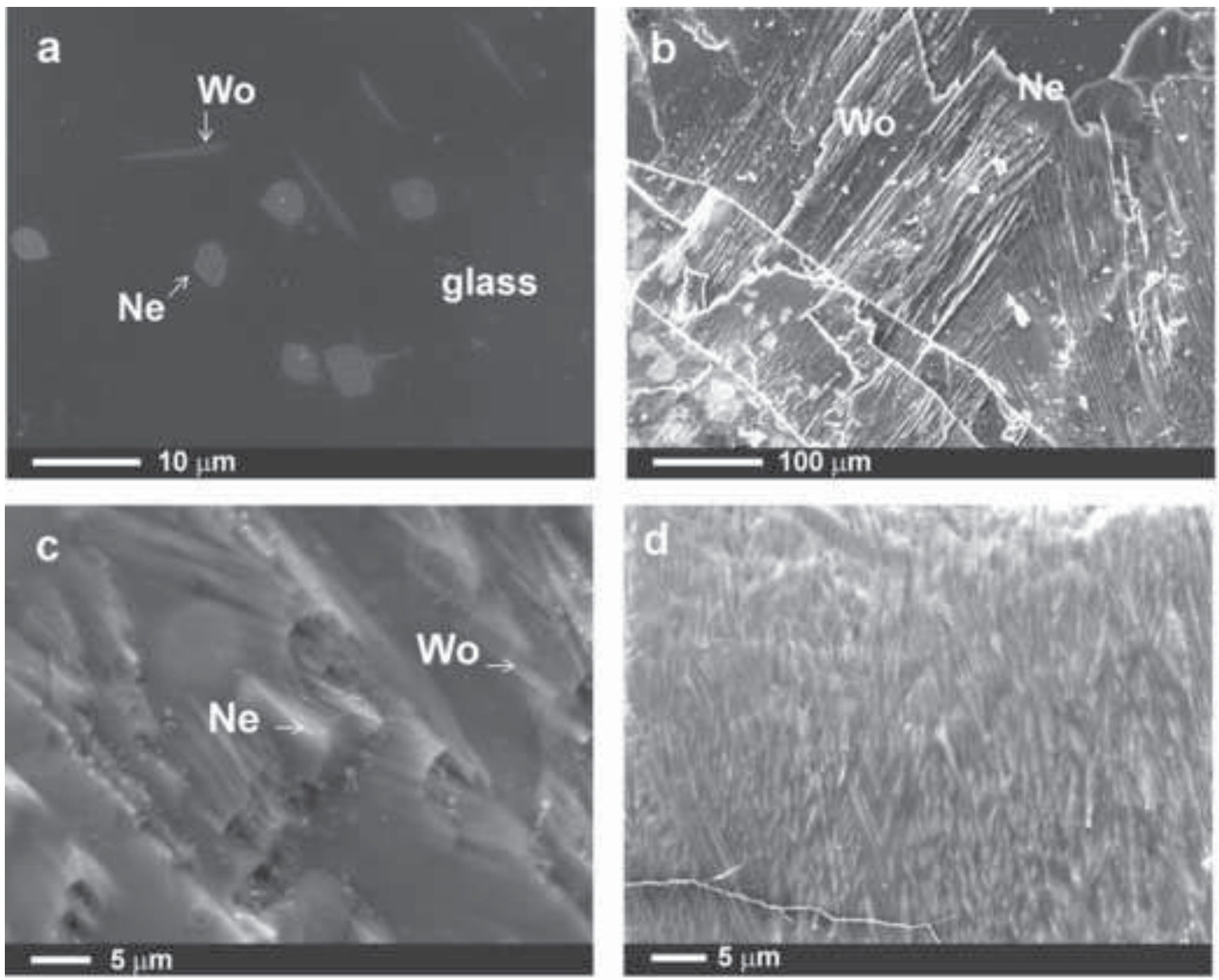
Table 1 Chemical composition of Barruecopardo tailings

\begin{tabular}{|c|c|c|c|c|c|c|c|c|c|c|c|c|c|c|c|c|c|c|}
\hline \multicolumn{10}{|c|}{ Major elements/mass $\%$} & \multicolumn{9}{|c|}{ Trace elements/ppm } \\
\hline & $\mathrm{SiO}_{2}$ & $\mathrm{Al}_{2} \mathrm{O}_{3}$ & $\mathrm{TiO}_{2}$ & $\mathrm{Fe}_{2} \mathrm{O}_{3}$ & $\mathrm{Na}_{2} \mathrm{O}$ & $\mathrm{MgO}$ & $\mathrm{CaO}$ & $\mathrm{K}_{2} \mathrm{O}$ & $\mathrm{P}_{2} \mathrm{O}_{5}$ & As & $\mathrm{Ba}$ & $\mathrm{Cr}$ & $\mathrm{Pb}$ & $\mathrm{Sn}$ & $\mathrm{Sr}$ & W & $\mathrm{Zn}$ & $\mathrm{Cd}$ \\
\hline BP1 & 74.4 & 14.5 & 0.2 & 1.3 & 2.9 & 0.3 & 0.6 & 5.4 & 0.4 & 363 & 157 & 16.0 & 27.9 & 14.6 & 42.4 & 753 & 38.0 & 2.9 \\
\hline $\mathrm{BP} 2$ & 75.3 & 13.9 & 0.2 & 1.2 & 2.9 & 0.3 & 0.6 & 5.3 & 0.4 & 291 & 172 & 4.7 & 27.8 & 15.6 & 42.8 & 908 & 38.0 & 2 \\
\hline BP3 & 76.0 & 13.3 & 0.2 & 1.2 & 2.5 & 0.2 & 0.5 & 5.6 & 0.3 & 256 & 212 & 8.3 & 29.4 & 12.6 & 49.7 & 919 & 44.6 & 2.6 \\
\hline BP4 & 75.6 & 13.7 & 0.1 & 1.1 & 2.7 & 0.3 & 0.5 & 5.6 & 0.4 & 397 & 163 & 7.4 & 26.5 & 14.4 & 41.3 & 735 & 32.8 & 1.6 \\
\hline BP6 & 75.8 & 13.7 & 0.1 & 1.1 & 2.8 & 0.2 & 0.5 & 5.5 & 0.3 & 223 & 144 & 11.6 & 24.5 & 13.2 & 38.0 & 859 & 33.0 & 1.5 \\
\hline BP7 & 75.6 & 13.7 & 0.1 & 1.1 & 2.8 & 0.3 & 0.5 & 5.4 & 0.4 & 545 & 169 & 9.6 & 26.0 & 14.4 & 42.9 & 772 & 31.3 & 2.4 \\
\hline BP8 & 77.7 & 12.4 & 0.1 & 0.8 & 2.2 & 0.2 & 0.4 & 5.8 & 0.3 & 632 & 183 & 16.6 & 24.7 & 9.8 & 43.1 & 617 & 26.6 & 2.2 \\
\hline BP9 & 75.9 & 13.1 & 0.2 & 1.3 & 2.3 & 0.4 & 0.5 & 6.0 & 0.3 & 123 & 185 & 24.3 & 21.1 & 11.3 & 48.6 & 719 & 30.0 & 2.4 \\
\hline BP10 & 74.9 & 14.1 & 0.1 & 0.9 & 2.7 & 0.2 & 0.5 & 6.2 & 0.4 & 83 & 169 & 5.7 & 24.6 & 10.5 & 41.8 & 677 & 27.7 & 1.6 \\
\hline BP11 & 76.6 & 13.3 & 0.1 & 1.0 & 2.6 & 0.2 & 0.5 & 5.4 & 0.3 & 236 & 157 & 16.9 & 24.7 & 13.5 & 40.5 & 757 & 34.6 & 1.5 \\
\hline BP12 & 77.7 & 12.8 & 0.1 & 0.9 & 2.5 & 0.1 & 0.4 & 5.1 & 0.3 & 262 & 107 & 20.9 & 23.3 & 15.7 & 31.9 & 1011 & 36.5 & 1.9 \\
\hline
\end{tabular}


Table 2 Chemical composition of the original glass.

\begin{tabular}{lllllllllll}
\hline $\begin{array}{c}\text { Oxides } \\
\text { /mass } \%\end{array}$ & $\mathrm{SiO}_{2}$ & $\mathrm{Al}_{2} \mathrm{O}_{3}$ & $\mathrm{TiO}_{2}$ & $\mathrm{Fe}_{2} \mathrm{O}_{3}$ & $\mathrm{MnO}$ & $\mathrm{Na}_{2} \mathrm{O}$ & $\mathrm{MgO}$ & $\mathrm{CaO}$ & $\mathrm{K}_{2} \mathrm{O}$ & $\mathrm{P}_{2} \mathrm{O}_{5}$ \\
\cline { 2 - 9 } & 58.99 & 10.69 & 0.11 & 0.89 & 0.01 & 8.20 & 0.20 & 16.40 & 4.21 & 0.28 \\
\hline
\end{tabular}


Table 3 Experimental temperatures for the fixed viscosity points (HSM) [23], glass transition point (dilatometry) [22] and workability temperatures.

\begin{tabular}{l|c|c}
\hline \multicolumn{1}{c}{ Viscosity/Pa·s } & \multicolumn{2}{c}{ Temperature ${ }^{\circ} \mathrm{C}$} \\
\cline { 2 - 3 } & Experimental & Calculated $^{*}$ \\
\hline Glass transition point $/ 10^{12.3^{*}}$ & 644 & 624 \\
First shrinkage/10 & 854 & 706 \\
Maximum shrinkage $/ 10^{7.2}$ & 989 & 772 \\
Softening/10.1 & 1179 & 884 \\
Ball/10 $10^{4.4}$ & 1253 & 935 \\
Half ball/10 & 1344 & 1006 \\
Flow $/ 10^{3.1}$ & 1406 & 1059
\end{tabular}

Calculated temperatures of the significant production viscosities

Lower annealing point $/ 10^{13.5}$

Upper annealing point $/ 10^{12}$

Forming range $/ 10^{8}-10^{3}$

Glass conditioning range $/ 10^{3}-10^{2}$

Melting range $/ 10^{2}-10^{1}$

\begin{tabular}{c|c}
595 & 602 \\
671 & 630 \\
$926-1419$ & $740-1071$ \\
$1419-1556$ & $1071-1211$ \\
$1556-1712$ & $1211-1416$ \\
$1190-1556$ & $891-1211$
\end{tabular}

* Calculated using the model by Fluegel [26] 